\title{
Reclaiming academia from post-academia
}

[Published in Nature Nanotechnology 3, 60 (2008)]

PHILIP MORIARTY is in the School of Physics \& Astronomy, University of Nottingham, Nottingham NG7 2RD, UK; e-mail: philip.moriarty@nottingham.ac.uk

Post-academic science, driven as it is by commercialisation and market forces, is fundamentally at odds with core academic principles. Publicly-funded academics have an obligation to carry out science for the public good, a responsibility which is incompatible with the entrepreneurial ethos increasingly expected of university research by funding agencies.

Is nanoscience the "first full embodiment of post-academic science"? Have many of the traditional core values of publicly-funded university science been eroded to the point where they are now "part of a scientific mythology"? And is it "morally bankrupt" to draw a distinction between "pure" and "applied" science? These claims, which were all made in a recent commentary in Nature Nanotechnology by Tom Vogt, Davis Baird and Chris Robinson ${ }^{1}$, certainly capture the funding zeitgeist in the UK. In their eagerness to implement the recommendations of the Treasury's Science and Innovation Framework ${ }^{2}$ and the Warry Report ${ }^{3}$, the research councils that fund the bulk of university research in the UK now insist that economic impact and relevance to "end users" (i.e. industry) must play a central role in the peer review process, despite widespread criticism ${ }^{4}$. Similar post-academic ${ }^{5}$ commercial drivers are also an integral part of public funding strategies in, for example, the EU (under the Framework programmes), the US and Japan. However, far from heralding exciting new opportunities for university nanoscience, I strongly believe that the post-academic ethos suffers from a number of flaws - it runs counter to core academic principles; it is ethically questionable in many cases; and its supposed beneficial impact on innovation is not at all well-established.

John Ziman, the physicist turned social scientist, clearly identified the dangers of the postacademic approach to science and put forward cogent arguments regarding the necessity of disinterested academic research: "In effect, post-academic science tries to combine, often in the same individual, two modes of knowledge that are ethically incompatible. Disinterested science is essentially a moral enterprise sustained by a tacit ethos of mutual trust. This ethos is being fatally undermined by enforced cohabitation with instrumental research." 

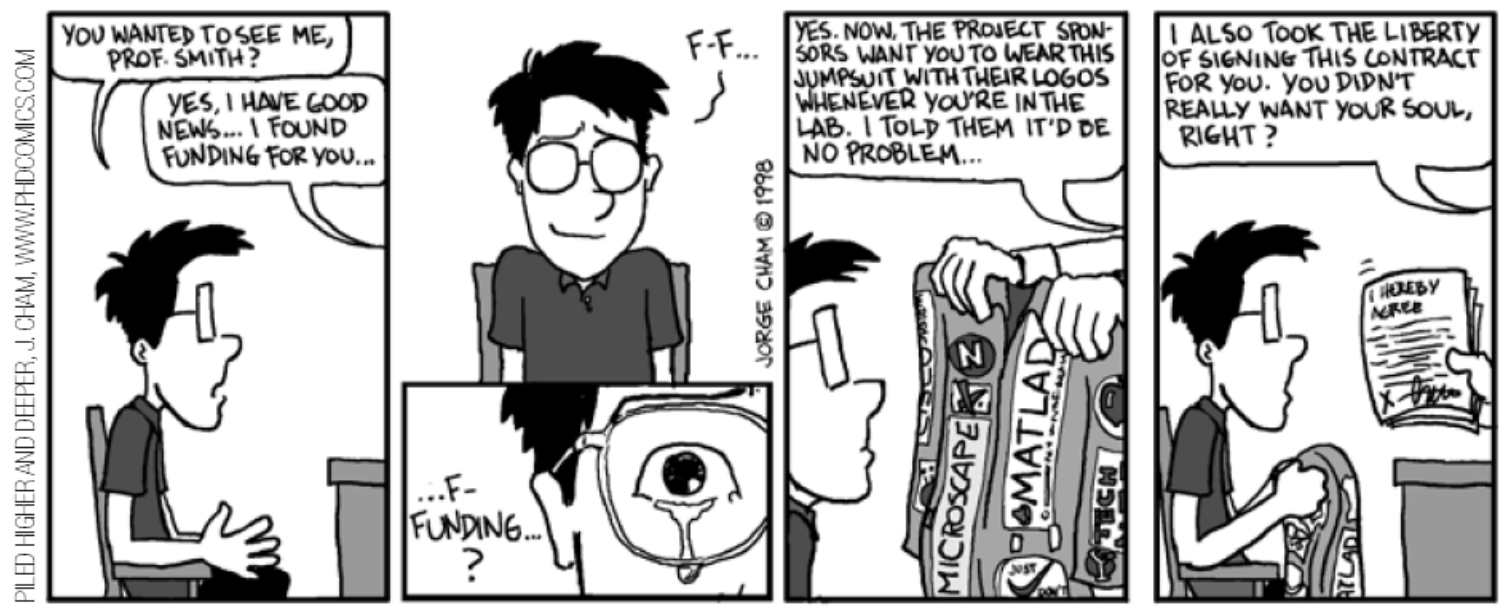

No laughing matter. Growing pressure to increase the economic impact of university research is compromising fundamental academic principles.

Ziman's definition of "non-instrumental science" is closely aligned with - although not synonymous with - the concept of pure science held by many academics. It is disinterested (i.e. not associated with particular material objectives/corporate goals); it is non-proprietary and entirely public; and it is open to exhaustive appraisal, critique and analysis. According to Ziman the ethos of non-instrumental science is entirely at odds with the commercial drivers which underpin instrumental science yet, crucially, "instrumental science itself, in the private or public sector, cannot prosper without non-instrumental science" ${ }^{\prime 6}$.

Ziman's forceful conclusion that the post-academic environment is eroding important academic traditions and, in turn, reducing the overall credibility of science, is echoed throughout Jennifer Washburn's excellent book, University Inc.: The Corporate Corruption of Higher Education ${ }^{7}$. Washburn describes a series of disturbing conflicts of interest driven by commercial corruption of US universities and puts forward a compelling case to support her argument that the strength of academia lies not in market-driven commercial product development but "in its capacity to appreciate the intrinsic value of intellectual discovery, human creativity, knowledge, and ideas".

There are of course those both within and outside academia who witheringly dismiss this ideal as part of a long-vanished or apocryphal "golden age". They argue that without the commercial product development, knowledge transfer, innovation, and economic competitiveness which 
apparently stem directly from publicly-funded instrumental research, taxpayers do not get "value for money".In this view instrumental research and "wealth creation" are synonymous with "public good". But how valid is this viewpoint?

\section{The public wants what the public gets}

Research councils and funding bodies universally conflate "wealth creation" with "public good" to justify the use of public funds to support instrumental research. Moreover, articles on how to commercialize nanotechnology, how to move from the lab to the market, and how to establish and run spin-off companies regularly appear in the pages of Nature Nanotechnology and other scientific journals and magazines. Yet where is the evidence that the public is getting value for money from the investment of its taxes in these activities? Indeed, careful analyses of trends in innovation lead to a rather unsettling picture of the efficiency of instrumental, market-driven academic research. In its 2003 report Keeping Science Open ${ }^{8}$, the Royal Society warned that the pressure to patent, to produce exploitable results, and to protect intellectual property have significant potential to impede scientific endeavour and, by extension, innovation. More pointedly, the report cites work by Richard Nelson of Columbia University ${ }^{9,10}$ which showed that the increased emphasis on academic patenting and technology transfer that was driven by the Bayh-Dole act, which came into force in the US in 1980, "has not much increased either technology or resultant net income". Other authors have reached similar conclusions ${ }^{7,11}$. Kira Fabrizio of Emory University is rather more direct and argues that "increasing university patenting is associated with a slowing pace of knowledge exploitation"12.

In a thought-provoking online discussion of the benefits of basic science, Chris Llewellyn Smith $^{13}$, while he was director general of the CERN particle lab, quoted Hendrik Casimir ${ }^{14}$, longtime director of research at Philips: "I think there is hardly any example of twentieth century innovation which is not indebted ... to basic scientific thought". Casimir provides a long list of examples of non-instrumental research, including advances in quantum theory, electromagnetism, and nuclear physics, which have led to pronounced economic impact (in the microelectronics, telecommunications, and nuclear power sectors respectively). We could add, for example, any or all of the following to the list: GMR and data storage, particle physics and the world wide web, the use of X-rays in medicine, the invention of magnetic resonance imaging, and the development of the scanning probe microscope (which many consider as the "genesis" of nanoscience). As Llewellyn Smith ${ }^{13}$ points out, in addition to the applications on Casimir's list being totally unforeseen, the discoverers "in general did not get rich". Such discussions are not 
restricted to the physical sciences: as The Lancet makes clear in its policy on conflicts of interest, "academics have a choice - to develop their entrepreneurial skills or to maintain a commitment to public-interest science - and we do not accept that the two options are mutually compatible." $15^{15}$

The argument here is, of course, hardly new: the generation of applications and spin-offs from basic blue skies research is commonly referred to as the "linear model" of innovation. This model has been criticised extensively and has now fallen very far out of favour ${ }^{16}$. It is clear, however, that reports of its demise have been exaggerated. A number of studies ${ }^{12,17-21}$ have established the efficacy of knowledge transfer from publicly funded academic research to industry via publications in the open literature, a core element of the linear model. In addition, the European Research Council was founded on a strong and refreshing commitment to basic science and a tacit acknowledgement of the ultimate economic benefits arising from noninstrumental research (as embedded in the linear model) ${ }^{22}$. As Llewellyn Smith states, "The demand that basic science should only be funded if the generation of specific benefits can be anticipated is misguided, and may actually be economically counterproductive." A recent Nature editorial puts forward a very similar argument $^{23}$.

More importantly, there are ethical and civic dimensions beyond simple value for taxpayers' money to consider in relation to the oft-lauded societal benefits of university-led wealth creation. At a recent workshop on the applications of nanotechnology in the developing world, Richard Jones $^{24}$ of Sheffield University made the very important point that funding agency fixation on wealth creation runs counter to the idealism of many scientists and does not address society's broader needs (ranging from the reduction of poverty and protection of the environment to, critically, the intellectual development of its citizens).

I would go further and say that it is the focus on market-driven wealth creation within publiclyfunded academic research, and not the distinction academics draw between "pure" and "applied" science ${ }^{1}$, which is morally bankrupt. Simply stated, competitive markets are ill-suited to the production or delivery of public goods ${ }^{25}$. Market forces not only fail to drive socially beneficial changes in the developing world, in the developed world innovation-led wealth creation certainly does not automatically lead to the establishment of a more equitable and, thus, better society. The gap between rich and poor in the UK continues to grow apace, with quite staggering levels of inequality in some areas ${ }^{26,27}$. 


\section{Return on investment?}

Last October the UK Science Minister, Ian Pearson, stated that the government "will make sure that at a strategic level they (the research councils) are making the right decisions. I want to see more economic benefit from the research base." Ignoring for now Pearson's blantant disregard for research council autonomy (the Haldane principle ${ }^{28}$ ), his comment resonates with a statement made in the editorial of the first issue of Nature Nanotechnology: "governments around the world are not investing billions in the field because the science is fascinating - they will want to see returns on their investments". There are three points to make in response to this.

First, pioneering and fascinating science is a return on government investment - this cannot be overstated. Quoting Ziman again: "Open-ended, disinterested research enriches society with influential, trustworthy, general knowledge." Second, while governments may well want to see a return on their investment, this will not happen unless they have invested wisely. Indeed, there is no strong evidence to suggest that the aggressive IPR and technology transfer regimes which necessarily arise from a government-driven "wealth creation" agenda yield a substantially better return on investment (in terms of innovation) than that available through traditional academic dissemination: as noted above, for example, the Bayh-Dole act in the US has hardly received universal endorsement with regard to its influence on innovation. Third, and most important, an economic return on investment should not be at the expense of traditional academic values including, most importantly, the concept of education (as opposed to training) as a public good, regardless of its role in innovation and wealth creation.

\section{Back to the future: Reclaiming academia}

I have argued that the post-academic world is fraught with logistical and ethical difficulties. A fundamental dichotomy exists between the instrumental research mode which forms the core of the post-academic model and the concept of non-instrumental science which embodies traditional academic values. Although the boundary between pure and applied research can be rather ill-defined ${ }^{29}$, the criterion of disinterestedness - and the associated openness and impartiality which naturally arise - provides a clear distinction between non-instrumental and instrumental research. Disinterest is key to scientific objectivity and, ultimately, the progress of science. Moreover, and crucially, it is not at all clear that the post-academic mode of research 
leads to improved innovation or represents a better return on public investment - where return is used in its broadest possible sense - than that possible via traditional academic methods.

In order for non-instrumental science to survive in a post-academic world, Ziman suggested in 2003 that the funding system should be "sufficiently indirect and loosely connected" so that individual peer-reviewed projects are protected from instrumental considerations. This suggestion echoes, for very good reason, the recommendations of the Haldane Report, which was published almost a century earlier and which laid the foundations for the creation of the research councils in the UK. Research council autonomy was seen by Haldane as essential to avoid pressures due to political expediency and administrative short-termism. An example of the dangers of direct political interference in the funding process is the recent (and flawed) commitment by the UK research councils to impose economic impact considerations within the academic peer review process. Given that the rate of economic return on basic research is effectively incalculable ${ }^{30}$, it is clear that a return to the Haldane principle, to ensure the development of rather more far-sighted funding strategies, is long overdue.

The evolution of post-academic science is, of course, not solely driven by funding bodies - the academy is complicit in establishing the predominance of instrumental research. But if public universities do not carry out disinterested, trustworthy science free of market and instrumental constraints, then who will? Publicly-funded scientists, regardless of whether they pursue research on the scale of nanometres or light years, have a moral obligation to address public needs, provide public goods, and to disseminate, not protect, knowledge stemming from their work. In the brave new post-academic world, this obligation is increasingly and incorrectly seen as a relic of a bygone age.

\section{REFERENCES}

1. T. Vogt, D. Baird, and C. Robinson, Nature Nanotech. 2, 329--332 (2007).

2. Science and Innovation Investment Framework 2004 - 2014; www.hmtreasury.gov.uk/media/5/B/spend04_sciencedoc_1_090704.pdf (2004).

3. Increasing the Economic Impact of Research Councils; www.dti.gov.uk/files/file32802.pdf (2006).

4. Corbyn, Z. Times Higher Education Supplement (12 October 2007).

5. Ziman, J. Real Science (Cambridge University Press, 2000) 
6. Ziman, J. Sci. Eng. Ethics 8, 397 - 399 (2002)

7. Washburn, J. University Inc.: The Corporate Corruption of Higher Education (Basic Books, 2005)

8. The Royal Society Keeping science open: The effects of intellectual property policy on the conduct of science; www.royalsoc.ac.uk/displaypagedoc.asp?id=11403 (2003).

9. Nelson, R.R Research and Technological Progress in Industry - An Analysis of the American Experience. Int. Sym. on Economic Development through Commerciallization of Science and Technology (2002);

10. Nelson, R.R J. Tech. Transfer 26, 13 -19 (2001).

11. Greenberg, D.S. Science for Sale (The University of Chicago Press, 2007)

12. Fabrizio, K.R. Ind. Corp. Change 16, 505 - 534 (2007)

13. http://public.web.cern.ch/Public/en/About/BasicScience3-en.html;

14. Casimir, H.G.B. Contribution to Symposium on Technology and World Trade (US Department of Commerce, 1966).

15. James, A., Horton, R., Collingridge, D., McConnell, J. \& Butcher, J. The Lancet 363 2-3 (2004)

16. See, for example, Fisk, D. Physics World 20, 16-17 (May 2007).

17. McMillan, G., Narin, F. \& Deeds, D. Research Policy 29, 1 - 8 (2000);

18. Tomes, A. Technovation 23, 785 - 792 (2003);

19. Liebeskind, J., Oliver, A., Zucker, L. \& Brewer, M. Organization Science 7, 428 - 443 (1996);

20. Narin, F., Hamilton, K.S. \& Olivastro, D. Research Policy 26, 317 (1997);

21. McMillan, G. \& Hamilton, R.D Scientometrics 72, 3 (2007);

22. European Commission High-level Expert Group Report Frontier Research: The European Challenge (http://erc.europa.eu/pdf/hleg-fullreport-frontier-researchapril2005_en.pdf) (2005).

23. Nature 448, 839 (2007).

24. Jones, R.A.L. Soft Machines (http://www.softmachines.org/wordpress/?p=359) (Posted Nov. 9 2007)

25. This fundamental premise of economic theory was reiterated very recently by Eric Maskin, one of the winners of the 2007 Nobel Prize for Economics. See, for example, Maskin's Nobel Prize lecture presentation available at http://nobelprize.org/nobel_prizes/economics/laureates/2007/maskin-slides.pdf 
26. Thomas, B. \& Dorling, D. Know Your Place: Housing Wealth and Inequality in Great Britain 1980-2003 and beyond, (Shelter Policy Library, 2004)

27. Dorling, D. et al. Poverty, Wealth and Place in Britain, 1968 to 2005 (Joseph Rowntree Foundation and The Policy Press, Bristol, 2007).

28. Report of the Machinery of Government Committee under the chairmanship of Viscount Haldane of Cloan (London: HMSO, Cd. 9230, 1918)

29. Calvert, J. Science Technology Human Values 31, 199 - 220 (2006)

30. Prime Minister's Strategy Unit Public Funding of Science; www.number10.gov.uk/files/pdf/06-09-29 public funding of research.pdf (2006).

\section{ACKNOWLEDGEMENTS}

It is a pleasure to acknowledge stimulating correspondence with James Wilsdon and Jack Stilgoe (Demos), Robert Doubleday (Cambridge University), Brian Wynne (Lancaster), Laurence Eaves, Michael Merrifield, Peter Milligan, Chris Satterley, Alison Mohr, and Brigitte Nerlich (Nottingham), John Costello (Dublin City), and Richard Jones (Sheffield). 